Article

\title{
Ordinary Places of Postmigrant Societies: Dealing with Difference in West and East German Neighbourhoods
}

\author{
Karin Wiest \\ Leibniz Institute for Regional Geography, 04328 Leipzig, Germany; E-Mail: k_wiest@leibniz-ifl.de
}

Submitted: 26 February 2020 | Accepted: 15 May 2020 | Published: 28 July 2020

\begin{abstract}
The starting point of the contribution is the question of how the dynamics of social encounters in the city are shaped by specific migration histories, local discourses, economies and policies. Against this background, the article analyses the perceptions and localised practices in dealing with social difference and diversity in a comparison of East and West German neighbourhoods. However, this is not about a hierarchizing evaluation, but about understanding urban encounters in the migration society as contestations of social and class recognition, which are played out at different levels and in specific urban places. Based on narrative interviews and field observations, it is shown how urban coexistence is experienced and negotiated in everyday settings between routines and new conflicts. A postmigrant perspective-as a heuristic point of entry-aims to take hegemonic understandings of societal belonging and exclusion under migration-related conditions into question.
\end{abstract}

\section{Keywords}

diversity; East Germany; encounter; postmigration; West Germany

\section{Issue}

This article is part of the issue "Urban Arrival Spaces: Social Co-Existence in Times of Changing Mobilities and Local Diversity" edited by Yvonne Franz (University of Vienna, Austria) and Heike Hanhörster (ILS-Research Institute for Regional and Urban Development, Germany).

(C) 2020 by the author; licensee Cogitatio (Lisbon, Portugal). This article is licensed under a Creative Commons Attribution 4.0 International License (CC BY).

\section{Introduction}

Referring to the many terms like 'arrival city' (Saunders, 2010) 'super-diversity' (e.g., Vertovec, 2007) or 'conviviality' (Wise \& Noble, 2016) urban research has recently focused on the significance of urban contexts, neighbourhoods as well as particular settings, which are characterised by international immigration, cultural diversity and fluctuation in an increasingly globalised world (e.g., also Albeda, Teersteg, Oosterlynck, \& Verschraegen, 2018; Hall, 2015; Saunders, 2010; Wessendorf, 2013). At the same time, these processes are accompanied by controversial everyday practices, discourses and policies in dealing with migration and diversity. Thus, new forms of comprehensive social inclusion, which are discussed and practised at different levels and which form the basis for equal participation in urban societies, are confronted with defensive reactions and new forms of exclusion, marginalization and discrimination (e.g., Foroutan,
2015). Against this backdrop, a growing interest is discernible in particular place-based configurations, which are shaped by different social dynamics due to their genesis, their integration into regional economies and local politics (e.g., Berg \& Sigona, 2013; Schmiz \& Räuchle, 2019). Correspondingly, scholars emphasize the fundamental role of specific local discourses, policies and constellations of actors, which impact the perception and handling of migration processes and the negotiation of social belonging and difference in urban contexts at different scales (e.g., Barbehön \& Münch, 2016; Biehl, 2015; Hinger \& Schäfer, 2019; Pott, 2018).

Against this backdrop, this contribution aims to approach interrelations between, on the one hand, local everyday practices and coexistence and on the other hand, discourses and development paths of urban migration societies. The focus was on the question of how in urban societies, that are characterized by migration and diversity, a sense of a commonplace is created, how difference is 
dealt with, and to what extent togetherness in the neighbourhood is entangled with the topic of 'migration' on different scales.

These questions will be investigated using the empirical example of two districts in the cities of Leipzig and Munich, which are shaped, among other things, by the respective migration histories in East and West Germany. In order to critically question essentialist, ethnically fixed research perspectives and a methodological nationalism (e.g., Glick-Schiller, Çağlar, \& Guldbrandsen, 2006) as well as problem- and potential-oriented perspectives on urban neighbourhoods marked by diversity and immigration (e.g., Pütz \& Rodatz, 2013), the article draws on a postmigrant perspective as a kind of heuristic entry point. In this respect, also the criticism of linear development concepts like integration and modernization paradigms, which impact prevailing ideas about living together in urban quarters, is an essential point. Here, the reference to 'ordinary' places and encounters also seeks to indicate a critical awareness of the reproduction of hierarchies between supposedly more highly developed and less developed urban contexts in dealing with difference, migration and diversity (e.g., Robinson, 2006). Against this backdrop, Section 2 outlines the critical-normative concern of a postmigrant perspective on society as well as the analytical consequences derived from it. In Section 3, the overall urban embedding of the two case studies investigated is introduced. This is followed by a presentation of the qualitative research approach (Section 4) and the empirical results, based on ethnographic field studies and in-depth interviews (Section 5).

\section{A Postmigrant Perspective on Urban Societies?}

Artists and activists, who aimed to raise critical awareness for the experiences of the descendants of 'guestworker' immigration in (West-)Germany, initially have introduced the catchphrase 'postmigrant society' to the German-speaking sphere (Langhoff, 2012). They intended to deconstruct the label 'migration' as a kind of extraordinary and stigmatizing status ascribed over generations and thus to fight against discrimination (Espahangizi, 2016; Langhoff, 2012). Against this background, the term has increasingly found its way into sociopolitical and scientific discussions. It has to be highlighted, that the suffix 'post' is generally negotiated less as a 'chronological after' than in the sense of an epistemological turn or the overcoming of hegemonic patterns of thought in order to rethink "the entire field in which the migration discourse is embedded" (Hill \& Yildiz, 2018, p. 7). In essence, it refers to a fundamental political recognition of the heterogeneous structure of society and the fact that migration fundamentally and ultimately irreversibly shapes coexistence (e.g., Bojadžijev \& Römhild, 2014; Foroutan, 2015). In the sense of a social-analytical approach, a 'postmigrant' perspective is, beyond others, dealing with those social constructs and power relations that are changing in the course of international mobility and networking and that produce new realities of coexistence (Espahangizi, 2016; Römhild, 2017). Therefore, a pivotal moment of the analysis must be seen in a critical examination of the contradictions and shifts that arise in the context of the social debates on migration and integration, which are concealing more fundamental negotiations in dealing with plurality under general conditions of globalization (Foroutan, 2018, p. 21). Negotiations of minority positions, ambivalences in the positioning towards 'migration,' and antagonisms between advocates and opponents of the plurality are representing characteristic points of friction and lines of conflict of recent (postmigrant) societies (El-Mafaalani, 2018; Foroutan, 2016). In this regard:

It is not a question of denying or discussing away the categories of migration and ethnicity, but rather of exploring how ethnicized and 'migrationalized' views of the world - of individuals, in institutions and politicsare produced, transformed and interact with other perspectives on societal 'difference.' (Dahinden, 2016, p. 8; author's translation)

Thus, the deconstruction of the social production of 'migration' as a result of historical and spatial categorizations and narratives of belonging or not belonging is central, based on which context-dependent boundaries between 'migrants' and 'non-migrants' are drawn (e.g., Amelina, 2017). Against this backdrop, in the frame of this contribution, the postmigrant approach aims to question majority social assumptions in urban and neighbourhood research from the perspective of a migration society. One task in this context is to overcome and deconstruct natio-ethno-cultural categorizations conceptually and at the same time the consideration of the societal obstacles, inclusions and exclusions associated with the attribution 'migration' in the urban everyday. In the frame of the empirical analysis, the postmigrant perspective is intended to raise awareness for a way of thinking about urban coexistence, with regard to the following aspects: In the sense of a de-marginalization of the diverse life concepts which are related to various migration biographies, the recognition of the contributions of 'newcomers' to urban coexistence, and the deconstruction of conflicts around the issue 'migration' as a proxy for disputes about social inequality, belongings and exclusions in urban societies.

The comparative case study presented in this contribution aims to trace the phenomena of postmigrant societies across sites and scales. The question of the differentiated constellations in which social coexistence in the neighbourhood can take shape is examined using the example of an East and a West German housing estate: The district Nordhaide in Munich in southwest Germany and the large housing estate Paunsdorf in the East German city of Leipzig. In this regard, both, the postmigrant and the comparative approach together form a kind of heuristic tool, to investigate the general, explorative question 
of urban coexistence under the conditions of growing mobility and migration. Here an understanding of case study comparisons comes to the fore which refers to the critique on fixed research entities and which is rather oriented on the investigation of phenomena and processes that are influenced by actors and events at different places and at different scales (e.g., Barlett \& Vavrus, 2017; Glick-Schiller \& Çağlar, 2009). By critically questioning dichotomies, static categories and self-evident notions, this comparative approach reveals important similarities with the core ideas of a postmigrant view of society. In order to make the empirical findings on the neighbourhood level comprehensible in their overall urban embedding, central urban development and integration policy lines for both cities are first outlined in the following section.

\section{The Case Study Design: Focus on East and West German Histories of Migration}

Even Munich and Leipzig are recently considered to be the most dynamically growing cities in Germany, different histories of migration shape local development and urban discourses. While integration and migration issues were little in the focus of urban development strategies in East German cities due to the dominance of emigration problems, shrinkage and small proportions of city dwellers of foreign origin, West German cities, in contrast, have been characterised by robust international migration flows and associated integration policy routines, since decades (Münch, 2013). The proportion of residents with an immigration background in the two case studies reflects those different development paths (Table 1). Here, $45 \%$ of Munich residents with a so-called 'migration background' show that multiple affiliations and transnational biographies are representing more or less the social norm in the Bavarian capital. For Leipzig, on the other hand, there are signs of a process, which might be interpreted as a kind of catch-up development to internationalisation. Although the proportion of inhabitants with a migration background currently appears to be relatively low at $15 \%$ compared with other cities in Germany, international immigration has become much more important in recent years. Apparent structural differences between the two cities under investigation are evident in the length of stay and the legal residence status of immigrants. The proportion of long-term resident migrants, but also those who belong to the second and third generation of immigrants, is significantly lower in Leipzig than in the Bavarian capital. At the same time, EU citizens dominate among Munich's residents who come from abroad, at just under $50 \%$. In Leipzig, on the other hand, temporary residence permits (38\%) determine the living situations of immigrants to a much greater extent (Figure 1). Even if a wide range of individual social situations is underlying these framework conditions, they indicate different overarching challenges and routines in dealing with immigration and difference in the two cities.

\subsection{Munich: A Super-Diverse Metropolis and the Importance of Immigration of 'Guest Workers'}

Along with Frankfurt am Main and Stuttgart, the Bavarian state capital is one of the major cities in Germany whose inhabitants are most strongly influenced by experiences of migration. The international immigration of workers recruited from 1955 onwards made a decisive contribution to Munich's economic boom in the 1960s and 1970s. The statement of the then Lord Mayor Hans-Jochen Vogel "Munich is a city of immigration!" marked as early as 1970 a paradigm shift in municipal policy recognizing the irreversible importance of migration for urban development (Hess \& Moser, 2015, p. 15). The significance of international immigration for the demographic and economic growth of the entire city region continued in the following decades. Between 1996 and 2015, international immigration accounted for around two-thirds of Munich's population growth. However, the main reasons why migration and integration are hardly ever problematized in public discourse in the sense of parallel societies are to be seen above all in the interplay between economic prosperity and an integration policy that is generally regarded as routine and is based on many years of experience in civil society and administration (Aybek, 2009). In a comparison of major German cities, Munich stands out for its lowest unemployment rates and highest purchasing power ratios for many years. This economic strength is reflected in the social composition of the city's inhabitants: The share of higher earners and qualified is generally high in a German city comparison-

Table 1. Socio statistical indicators and research design.

\begin{tabular}{lcccc}
\hline & Leipzig-Paunsdorf & City of Leipzig & Milbertshofen/Am Hart* & City ofMunich \\
\hline Inhabitants with 'immigration & 18.2 & 15.4 & $62.0\left(74.2^{*}\right)$ & 45.1 \\
background' in 2019 (\%) & & & & \\
2020 City Council Election & 26.3 & 14.9 & 5.5 & 4.4 \\
AfD (right-wing party; \%) & 43.1 & 59.7 & 36.3 & 49.0 \\
Voter turnout (\%) & 8.9 & 4.7 & 3.2 & 2.8 \\
Unemployment rate in 2019 (\%) & &
\end{tabular}

Note: * Nordhaide belongs administratively to the District 11 Milbertshofen-Am Hart. 
status of residence

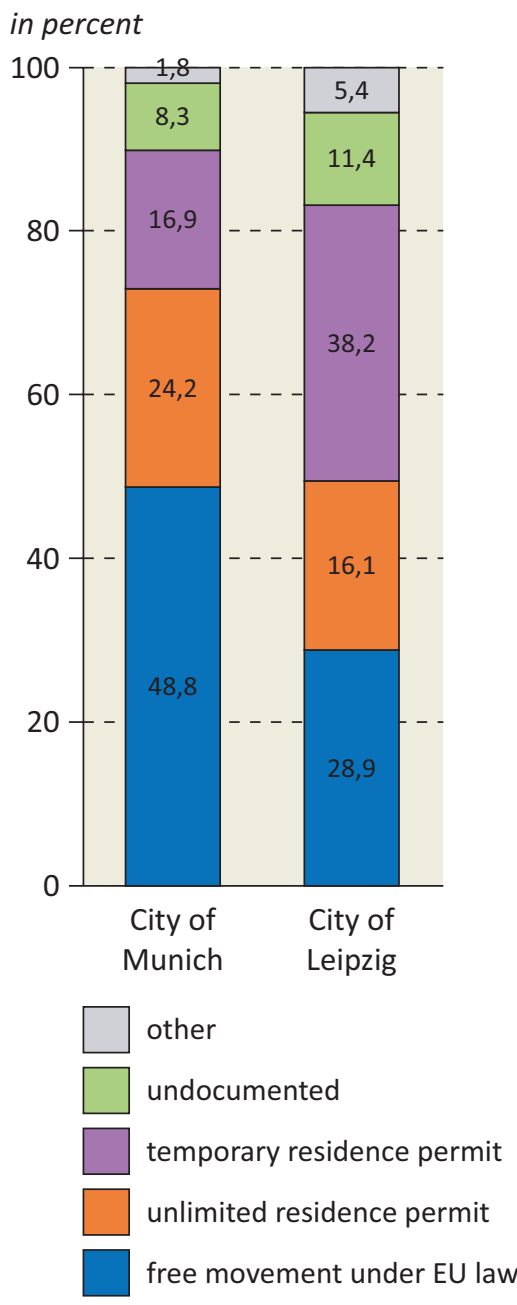

length of stay

in percent

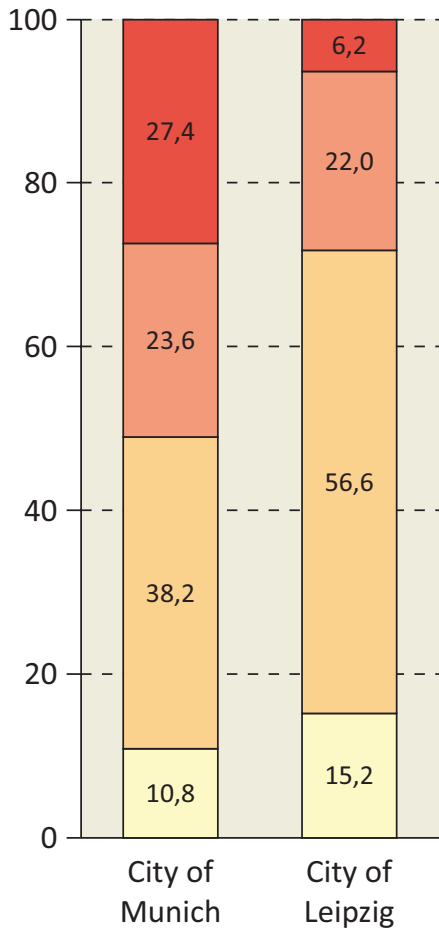

$$
\begin{aligned}
& \square \text { more than } 24 \text { years } \\
& \square \text { 10-24 years } \\
& \square \text { 2-9 years } \\
& \square \text { fewer than } 2 \text { years }
\end{aligned}
$$

Figure 1. Residence status and length of stay of the foreign population in Munich and Leipzig (\%) in 2019. Source: Wiest (2019), based on data from the Federal Statistical Office, Wiesbaden, 2019.

also among Munich's migrant population (Huss, 2010). At the same time, under the conditions of a tense housing market and corresponding living costs, even middleincome groups have difficult access to housing. Against this backdrop, the state capital has already been trying to counteract social segregation processes in the urban area with the instrument of 'socially just land readjustment' since the mid-1990s. In the planning of the study example of Nordhaide, this strategy has been fully employed (subsections 3.3 and 5.1).

\subsection{Leipzig: A Demographic Exception in East Germany?}

In the context of Leipzig's urban development policy, the significance of migration is being discussed primarily against the background of a long-standing negative population trend. Until the end of the 1990s, the city had to struggle with the structural problems typical of East German municipalities, like in particular substantial outmigration and ageing. International immigration was perceived above all as an opportunity in the fight against va- cancies and decay (City of Leipzig, 2013, p. 29). As the city increasingly developed from a shrinking to a growing metropolis in the 2000s, the social composition of those moving in also changed. Since 2010, international immigration increasingly influenced Leipzig. Accordingly, the proportion of the population with an immigration background has risen significantly from $6 \%$ in 2000 to $15 \%$ in 2019. In the course of these processes, the issues of migration and integration have come more and more into focus, both for economic promotion and urban development planning. Leipzig's strategic orientation is centred on the image of the "cosmopolitan and tolerant city," which refers to the city's traditional trade fair and trade functions (City of Leipzig, 2018a, A-15). In these contexts, xenophobia is perceived as a particular threat to a positive image and competitiveness in interurban competition. Accordingly, the city is trying vigorously to distance itself from the image of East German xenophobia (Wiest \& Kirndörfer, 2019).

At the same time, under the conditions of growing demand on the housing market, segregation of social strata, 
but also ethnic affiliations, are increasingly perceived as a threat to social cohesion (City of Leipzig, 2018a, C 2.5-13). In a comparison of major German cities, sociospatial inequality, concerning indicators such as unemployment rates and educational qualifications, but also of residents with an immigration background, is striking in East German cities such as Leipzig (Helbig \& Jähnen, 2018). These patterns become particularly evident in the large housing estates on the outskirts of the city. Here, new development perspectives were emerging after a long phase of shrinkage due to the influx of refugees between 2014 and 2016. The settlement of Paunsdorf, which was the focus of the study, is an example of these processes.

\subsection{Munich Nordhaide and Leipzig Paunsdorf: Two Housing Estates on the Outskirts of the City}

Even the settlements of Munich Nordhaide and Leipzig Paunsdorf have been little in the focus of local public and media attention, they both represent constellations which can be regarded as typical for the migration histories and the internationalization process of the two cities studied. Between 1999 and 2011, the district Nordhaide as was newly developed as part of an urban development project in the northern outskirts of Munich (LH München, 2012). Despite the generally high proportion of international residents in Munich, this district stands out in this respect: $74 \%$ of Nordhaide's inhabitants have a so-called migration background, which representing various generations of immigrants and regions of origin (Table 1). However, the internationality of the population is not primarily because the area is the first destination for newcomers in the city. It is also related to inner-city relocation chains and the employment structures in nearby companies and the working places of the generation of 'guest workers,' such as the BMW facilities. From the very beginning, the planning concept of Nordhaide was directed towards a heterogeneous social structure, promoting encounters between different groups of residents and providing a wide range of housing for different income groups with publicly subsidised rental housing, privately financed rental housing and owner-occupied and rental housing subsidised by the City of Munich (Empirica, 2011).

The Leipzig study example, Paunsdorf, was built from 1985 onwards as one of the last large housing estates of the German Democratic Republic's industrial prefabricated concrete panel construction. From 2013, after a pronounced phase of population shrinkage, it gained in importance as a destination for international immigration - a development that was initially related to the importance of the neighbourhood for the accommodation of refugees. Although it is not one of the districts of Leipzig with the highest proportion of citizens with an immigration background, the housing estate is attributed an "increasing role in the integration/inclusion of residents with an immigration background due to the signifi- cantly increasing proportion of foreigners in the district" (City of Leipzig, 2018b, p. 2, Table 1). In particular, the coincidence of an "above-average proportion of migrants with a disadvantaged German population" with urban peaks in old age and child poverty is perceived as a challenge for social urban development policy (City of Leipzig, 2018b, p. 36, Table 1).

\section{Research Design: Ethnographic Fieldwork and Narrative Interviews}

For the research on urban coexistence and dealing with diversity, the study referred to an understanding of space that defines 'neighbourhood' as "a contextually embedded central location of everyday life and individual social spheres, socially constructed by external and internal actions, but blurred contoured" (Schnur, 2008, p. 40). Even more than neighbourhoods, concrete places and institutions are considered as focal points where multiple traditions, experiences and knowledge encounter. For example, kindergartens and schools, but also libraries, youth clubs and residents' centres can be cited as appropriate fields in which the negotiation of societal plurality can be explored. Accordingly, intensive phases of participatory observation took place between winter of 2017 and spring of 2019 in local youth clubs, neighbourhood houses and self-organised women's cafés. The observations were documented in detail by field notes. Beyond that, the research team regularly visited neighbourhoodrelated working groups, network meetings and district festivals, to some of which it actively contributed.

43 guideline-based narrative interviews respectively discussions in small groups with residents (11 in Paunsdorf and 10 in Nordhaide) and with representatives of sociocultural and educational institutions (e.g., kindergartens, day-care centres, residents' centres, local associations, social workers, politicians; 11 in both Nordhaide and Paunsdorf) provide a further empirical basis. Within the framework of already existing contacts, the interviewees were contacted via multipliers and via snowball system. In order to enable interviewees to unfold narratives about coexistence and biographical experiences from an individual perspective, without suggestively influencing them, narrative stimuli were given that were kept rather general and neutral. The questions targeted neighbourly relations, the situation of newly arriving, how encounters between people of different origins and changes of the neighbourhood were experienced, how commitment and involvement into local institutions came about and about the role of (multiple) belonging to regions of origin. The narrative interviews were conducted in German, although the language skills of the interviewees were very different. In some cases, language mediators supported communication.

The analysis of the text material-transcribed interviews and field notes-is oriented on the logic and interpretation guidelines of a Grounded Theory (Glaser \& Strauss, 1979; Przyborski \& Wohlrab-Sahr, 2014). Thus, 
a category-based interpretation scheme was developed, referring to a 'postmigrant society' as a heuristic frame. The following questions were addressed to the material: Which inclusions and exclusions are relevant or discernible? (How) is the topic of 'migration' instrumentalized? To what extent and in what contexts are nationalethnic-cultural origins addressed? Are internationality and diversity regarded as irreversible processes? Can inclusive exclusions of 'migration' be identified? What role do places of encounter play (in terms of learning, inclusion and exclusion, representation)? The intention was to trace subjective-individual insights as well as the range of subjective interpretations and explanatory patterns that reflect general site-related structures but cannot be causally derived from them and which are integrated into overarching contexts and interdependencies.

\section{Dealing with Diversity in Nordhaide and Paunsdorf: Unquestioned Normality, Struggles for Recognition and Mirror of Urban Inequalities}

The following consideration of everyday settings on the neighbourhood level aims to make the different perspectives and practices of actors comprehensible and to approach the structures that generate a sense of shared place or belonging in the respective local societies shaped by diversity. The consideration of an East German and a West German neighbourhood also indicates how different local framework conditions intertwine with overarching urban discourses and influence the negotiation of difference and diversity.

\subsection{Munich Nordhaide: Normalcy of Otherness on the Margins of the Cosmopolitan Metropolis}

When entering the local shopping centre Mira or the Metro station, the multiplicity of languages, migration biographies, educational and religions backgrounds of Nordhaide's inhabitants is striking. Older residents belonging to the first generation of immigrants are standing beside newcomers from outside Europe, while younger inhabitants of the second or third generation of immigrants, who grew up in Munich are passing in groups. Several playgrounds and arranged seating arrangements characterize the public space. Less visible to the visitor is the institutional setting of the residential area, which is characterised by numerous social and childcare facilities that provide important opportunities for the development of social networks and interaction. An important key actor in this regard is the Diakonie Hasenbergl e.V. who is running an open children's club, a kinder garden, a residents' centre and is initiating several neighbourhood projects. Although the Diakonie is representing the protestant church, the diversity of religious, cultural and national backgrounds of staff and clients shapes the everyday work in many of their projects. It may indicate, that 'diversity' stands out as a dominant categorization of the local reality in the North of Munich. Based on field notes, the following section will sketch everyday life in the residents' centre Nordhaide in order to demonstrate how different biographies and individual experiences meet in one place and how the coexistence of different groups is negotiated.

\subsubsection{The Residents' Centre as an Instance of Everyday Cosmopolitanism}

M., a young German teacher originating from Uzbekistan and now the leader of the residents' centre, welcomes me and reports some news: Christmas went well, there were many children there, a volunteer played Santa Claus. Soon they also want to celebrate the Muslim breaking of the fast. Then O., a young woman from Belorussia, comes in, she is doing her internship. When discussing the different offers of the institution, it occurs to her that they do not yet have any offer for men. The bike workshop and a games evening are mentioned. W., a German pensioner, is in the house every day to check on things, which seems to be an important anchor point for her. She considers the centre to be her family, "because her family does not care.' Much of the work is about getting the neighbours out of their apartments. For example, S., a young mother with Turkish roots, was motivated by the staff members to organize a women's breakfast. Besides possibilities of voluntary employment and to improve her German, S. is also interested in community and joy without a specific purpose. Many women participated in her breakfast due to mouth-to-mouth propaganda, and S. considered it as a great personal success. It is only one example how-besides concrete solutions to problems and opportunities to earn additional income-the different projects, above all, open up new, everyday communication spaces. An essential event in this respect is also the common lunch table of the resident's centre, where all employees, some residents and school children of different origins, language skills and backgrounds are gathered. At the table, they chat about common everyday problems like housekeeping or difficulties in school-sometimes in different languages. The atmosphere is cheerful and relaxed. (Shortened field notes of October 26, 2017, February 6, 2018, and February 15, 2019; Pilz, 2019).

The participating field observations illustrate that conviviality across ethnic and cultural differences in the resident's centre is unquestioned normality or a kind routinized coexistence (e.g., Berding, 2019; Wessendorf, 2013). Much suggests that the different biographies and origins of the actors create a space of group identification that is not based on ethnic, national or religious affiliations, but on joint work, on activities but also biographical experiences as women and mothers. Everyday life in this setting thus comes across as an instance of everyday cosmopolitanism. Conviviality refers to this particu- 
lar place and shared interests rather than on ethnicity or origin. The interactions and offers enable the formation of social networks, and the transfer of everyday practical information, resources like assistance for school children as well as emotional support. An important issue for the success of the offers are the personal migration histories of key actors (see, e.g., NH_Ex4, NH_Ex5, and NH_B6 in the Supplementary File). At the same time, it became clear in various interactions in the neighbourhood that supposed cultural conditions and attributions are repeatedly used as explanations for societal questions and problems (Pilz, 2019, p. 41). One recurring, underlying motif in this context is the representation of a Munich society, which is considered to be progressive, tolerant and affluent-and which is represented by middle-class citizens, usually with German roots. This image is called into question, is controversial debated and at the same time continually being consolidated-however, it is ultimately still present in many professional positions and institutional hierarchies (see, e.g., NH_Ex3 and NH_Ex5 in the Supplementary File).

\subsubsection{Who Belongs to the City?}

That Munich's North or rather the Nordhaide is continuously and irreversibly shaped by a variety of origins and migration biographies is a hardly questioned issue among the inhabitants. However, while the issue 'diversity' refers in the overall urban context to a progressive, tolerant urban society, it appears in the case of Nordhaide, as the feature of a special case or deviation, instead. At the same time and despite the existing national-ethno-cultural diversity in the neighbourhood, a kind of dominant culture which is supposed to be 'German' is continuously referred to in talks and everyday encounters. This imagination seems to represent an anchor for daily work and coexistence, and its questioning is sometimes seen as a threat to the smooth functioning of everyday life. Attempts to make an effort of 'all' cultural traditions and origins was viewed critically in some of the talks (see NH_B5, NH_B2, and $\mathrm{NH}$ _B9 in the Supplementary File). In this regard, residents with own migration biography-in particular the generation of 'guest workers'-mentioned the impression of a devaluation of own adaptation and integration achievements (see, e.g., NH_B2, NH_B4, and NH_B5 in the Supplementary File).

That an idea of a Munich majority society of German origin is still present in people's minds is somehow reflected in the statement, that the low proportion of inhabitants with German roots in the neighbourhood is considered as unfavourably. To some extent, this finding was interpreted as a dissociation of the middle-class society from Nordhaide. Related is also the underlying assumption that Munich citizens of German origin tend to live in Nordhaide only when they are more or less in precarious situations (see, e.g., NH_B2, NH_B4, NH_B9, and $\mathrm{NH}_{-}$Ex3 in the Supplementary File). Both assump- tions mirror the persistence of the traditionally rather low reputation of the north of Munich, in which the issues of social disadvantage and 'immigrants' are simultaneously entangled. This interrelation is also implicitly reflected in the following conversation with a young woman. However, she emphasizes the diversity in Nordhaide as a characteristic feature of contemporary urban societies and, at the same time, clearly insists on belonging to Munich.

But for us, we're slowly getting used to it [internationality and diversity]. Find it's just part of the package. This is our Munich now. That's why I believe that some people say 'Yes, it was not so loud and so on.' And...it's just getting used to it. But when you've seen it, when you see it all the time in front of you, you see that it's normal. This is Munich. (NH_B8 of the Supplementary File)

Also, the following quote from a conversation with a local social worker reflects issues of belonging and recognition in urban migration societies. On the one hand, the interviewee emphasises the integration achievements of young people with a migration background, which in essence, however, are equated with efforts in the field of education. On the other hand, she has a lot of understanding for their frustration about still being supposed not to belong to Munich's society or to be treated as foreign:

But you live there, you have a German passport, you do your technical college, and even if that is nicely meant, with those questions, e.g., 'where are you from, can we help?' and so on, it is not nice for the young people. Because we want integration and that they (the young people with migration biographies) feel German and also act as German and then they do it, so they do everything right.....And then they are treated as if they came 'from the bush.' (NH_Ex3 of the Supplementary File)

The criticism of the social worker refers to the fact that other members of society do not adequately recognise precisely these 'integration' achievements of young people. At the same time, this also reflects a clear acceptance of the need for social integration into a host society in a relatively traditional way. Underlying to this argument is an understanding of modernity, in the sense of a developed, modern and progressive Munich city society, vs. supposed backwardness of other forms of societies-an aspect, which is at the heart of postcolonial critique (see, e.g., Ha \& Schmiz, 2006). This perspective can preferably unfold in the consciousness of living in an urban region that is perceived as attractive, economically strong and largely cosmopolitan, and is not suspected of being affected by racism (see, e.g., NH_Ex3 and NH_Ex4 in the Supplementary File)-a situation which differs from the Paunsdorf case. 


\subsection{Leipzig Paunsdorf: Politicisation and Polarisation through the Lens of Migration}

We enter the family centre, and a completely different atmosphere opens up to us. It's like entering a parallel universe. We come from the Paunsdorf, with its prefabricated concrete building and its almost deserted streets, and meet lively activity in the slightly dilapidated premises. Children bustle around, you hear loud confusion and talk. In the kitchen, it is very crowded. Many women are standing in it....Everyone is talking to each other. We are noticed and curiously patterned, but the mood does not change much. After a short 'scanning,' we are treated quite commonly. We are not excluded. (Fieldnotes from March 5, 2018)

This brief field note from the family centre, where women with flight biographies meet with their children to cook and eat together with other women, describes the setting of a self-created space of coexistence, which may, at first glance appear similar to initiatives in Nordhaide. Since the large-scale housing estate Paunsdorf has gained in importance for the accommodation of refugees since 2014/2015, the number of children with an immigrant background rose sharply. New tasks, like language problems and different cultural habits, posed new challenges for everyday life in schools and kindergartens. In this situation, a youth club on the outskirts of the district attracted the newcomers more than other institutions and became a particular resource for families with a history of flight-not only for young people but also for their parents. It was at the centre of the ethnographic fieldwork in Paunsdorf.

\subsubsection{The Youth Club: A Protective Space for Different Needs}

The club is more crowded now: All the PlayStation seats and the billiard room are occupied. I'm called to table tennis; the big boys' team wants to join. This premises on the outskirts of the city form a kind of own centre. In addition to leisure activities for young people, it takes among others, on the functions of a residents' centre, a canteen and a (migration) counselling, but also enables self-organized projects-like the women's café initiated by L. a young mother origination from Palestine and threatened by expulsion. Despite lacking resources, however, with enthusiasm, the urgency of 'responsibility for integration,' caused by the influx of residents with histories of flight into the neighbourhood, was accepted by the two permanently employed pedagogues voluntarily. Around $5 \mathrm{PM}$, there is soup-especially the younger children are joining; for them, lunch is essential. M. shouts 'halal' loudly when the meal is announced, but he does not eat with them. The older 'Arab' boys often go to Aldi and buy snacks. The 'German' children seem to have no money; they have to wait for the soup. How the parents experience this and how social tensions arise, can be guessed. Here the pedagogues regularly provide information. An essential part of their positioning in the club is the work 'against the right-wing radicals.' (Shortened field notes from February 21, 2018; Kirndörfer, 2019)

The observation in the youth club showed, among other things, what happens when different marginalised groups step out into a public space which on the one hand, is representing a municipal institution, but is, on the other hand, a protective space, characterised by openness and affection for multiple needs and aspects of difference (Kirndörfer, 2019). Here the young people experience recognition and can also bring their own rules into play. Beyond that, it is a place of support for families in distress. In doing so, the youth club appears as a place where cautious encounters and multiple activities can break down simple labelling of differences and encourage new bonds. However, the process of becoming part of the existing social fabric, characterised by poverty and social precarity, provokes struggles for recognition, attention and trust (Kirndörfer, 2019). The distribution and recognition conflicts, the negotiation of rules in everyday life of the youth club is not least embedded in the superordinate coexistence in the neighbourhood context and is affected with the supra-local discourse on 'the German East' and the radical right-wing question.

\subsubsection{Paunsdorf and the Discourse on the German East}

Political phenomena like the upcoming of the AfD, a right-wing and xenophobic party in Germany and the PEGIDA (Patriotic Europeans against the Islamisation of the West) movement, a xenophobic, right-wing populist organisation that has been organising demonstrations in the city of Dresden since October 2014, have gained in importance, especially in the Eastern parts of Germany. These circumstances are reflected in the local voting behaviour, with high proportions of AfD voters, but also non-voters, for example, compared to the Munich case study. Also, in comparison to the city average Paunsdorf strikes out in this respect (Table 1). Experiences of racism (see, e.g., P_B2, P_B7, and P_B11 in the Supplementary File), xenophobic attitudes and overall discourses about the German East strongly impact everyday encounters as well as patterns of interpretation and interaction in Paunsdorf (P_B4, $P_{-} B 11$, and $P_{-} E x 7$ in the Supplementary File). Against this backdrop, interviews and field research has shown a firm intention among many actors in local institutions, like among others kindergartens and youth clubs, to counteract increasing right-wing populism and anti-immigrant sentiments (see, e.g., $P_{-}$Ex 3, P_Ex6, and P_Ex10 in the Supplementary File). Thus, committed actors interpreted their daily work not only as a task in the field of social work-much more it is perceived as an explicit political contribution, as the following example of the youth work- 
ers in Paunsdorf shows:

It is difficult to place political topics. The parents say, for example, that there are migrants; I don't want that you go there, it is dangerous. So, and then you know, okay, that's the way the work is needed. And somehow you have a position that is against it so that you simply come into an exchange with young people and don't say okay, we are now doing a political project here. But that they just see, cool, there are somehow people who come from outside; they have a left-wing attitude. And dad says left-wingers are, uh, are all weird guys, but you're kind of cool that way, and that you're just a role model for them. (P_Ex10, Supplementary File)

In other discussions, representatives made clear that the topics of migration and integration are complicated to convey. They are considered too provocative and should not be addressed if you want to achieve your goals. In this way, dealing with difference and migration has virtually become a taboo subject in the local society (see, e.g., P_B11 and P_Ex6 in the Supplementary File). In the following case from daily work in a day-care centre, the vulnerability towards the topic xenophobia becomes clear once again. Here it refers to the reproach of xenophobia raised by a child of the group to a team member. The nursery-school teacher interviewed was in a kind of intermediary position in this conflict:

So, when we recently sat together with the team, and this became the topic again with this, 'the child said to me, I am xenophobic' - this has deeply affected the teacher because she says: 'Oh, that has me/I don't know at all how to deal with this.' And then: 'That's not true either.' Then, when we had finished with the topic so far, I said again: 'Yes, I come from a typical guest-worker family [Turkish inmigrants to western Germany, who migrated later to eastern Germany], I know what it means to be...treated xenophobically.' (P_Ex8, Supplementary File)

Therefore, primarily because of her complex migration biography, she felt to be entitled, to evaluate the events neutrally and thus to act as an advocate for her (East German) colleague in this particular case. Not at least since staff with migration biographies usually still lacks in the local institutions, it is more uncertainness how to deal with the ethnocultural difference in everyday life. However, these different examples show that the public discourses on migration and natio-ethno-cultural differences are present and relevant points of references in everyday work and communication in Paunsdorf. Even if migration-related diversity is less visible in Paunsdorf compared to Nordhaide, it is still a dominant theme in the coexistence-in the sense of a proxy for struggles around left and right-wing attitudes, and in conjunction with racism as a permanent underlying issue, stress-free encounters seem challenging to realise. Here, the youth club offers newcomers first of all an essential space in which difference becomes possible, and which represents in the case of the women with flight biographies, in particular, a place of protected intimacy (Kirndörfer, 2019). Hence, the high value of places in the neighbourhood, becomes particularly evident where low-threshold encounters are possible, and people work together cautious, in rather unspectacular interactions and situationspecific encounters, such as youth clubs, day-care centres, family centres or other associations.

\section{Ordinary Places and Actors of Urban Migration Societies}

The juxtaposition of the two districts Leipzig Paunsdorf and Munich Nordhaide illustrated how paths of urban migration histories and overall socioeconomic framework conditions influence the local negotiation and subjective perception of migration and diversity in the urban every day. Due to considerable and rapid changes in the social composition of its residents, the handling of international immigration in Paunsdorf was more often problematized in connection with overburdening and distributive justice-not least concerning a supposed lack of public attention for this district and its residents. This applies to some extent, also for Nordhaide. However, in this neighbourhood, a rather unexcited and routinized coexistence among residents can unfold against the backdrop of the consciousness of living in an urban region, which is perceived to be, beyond others, economic attractive and largely cosmopolitan. Leipzig, in contrast, is struggling more intensively with tensions in dealing with of increasing societal plurality against the backdrop of various frictions after the political changes and the overall realities and debates of racism and growing xenophobia in East Germany. Hence, the case study examples illustrate, how dealing with natio-ethno-cultural difference is practised on the local level is not at least shaped by particular discourses on the supra-local scale.

If a postmigrant society is first of all considered as a society in the process of negotiating its identity and future under the terms of global mobility, then these negotiations are conducted in Paunsdorf more strikingly and vulnerable than in Nordhaide. Even though the effects of different urban migration histories as well as socioeconomic contexts are of considerable relevance in both case studies, a development-oriented perspective must be called into question. From a corresponding perspective, the Munich case study could appear as an idealtypical pioneer in dealing with natio-ethno-cultural diversity and difference. Leipzig-Paunsdorf, on the other hand, could, in the sense of a linear model of migrant incorporation, be misunderstood as a sample for a 'catchup development.' More relevant than hierarchical evaluations are therefore analytical perspectives that consider places of encounters and conviviality in the migration society simultaneously as contested places of so- 
cial and class recognition on different scales. Foroutan (2016), for example, assumes that postmigrant societies are precisely characterized by the growing tensions between those who understand democracy as equal rights for all citizens and those who demand more rights for their group, be it defined, ethnically, religiously or nationally. In the Paunsdorf example, these tensions appear rougher and more polarizing-and also refer to unequal power relations in the national context. At the same time, the daily work of the people in the local institutions is continuously questioning and temporarily abolishing the influence of overall political and societal discourses in everyday situations. This was, beyond others, shown by women's cafés, in the premises of the youth club Paunsdorf as well as in the residents' centre in Nordhaide, organised by individual women: In the different settings, these events developed similar open dynamics of togetherness. Beyond that, everyday life frequently reveals, that not ethnic-national-cultural affiliation but first of all the financial, educational and social access to certain offers in the urban societies under consideration makes the difference in coexistence. In this context, the studied examples in Munich as well as in Leipzig show the importance of the 'ordinary' places and their actors, where participation is struggled for, and recognition is experienced, and who thus actively contribute in shaping urban society.

\section{Acknowledgments}

Particular thanks go to the staff of the DFG research project "Dealing with Diversity on the Margins of the Postmigrant City," especially to Elisabeth Kirndörfer and Madlen Pilz for extensive participating field observations and in-depth analyses in the Youth Club Paunsdorf and the Residents' Centre Nordhaide, Dilan Karatas and Luise Postert for supporting the in-depth interviews. The article greatly benefited from helpful suggestions of three anonymous reviewers.

\section{Conflict of Interests}

The author declares no conflict of interests.

\section{Supplementary Material}

Supplementary material for this article is available online in the format provided by the author (unedited).

\section{References}

Albeda, Y., Teersteg, A., Oosterlynck, S., \& Verschraegen, G. (2018). Symbolic boundary making in superdiverse deprived neighbourhoods. Tijdschrift voor Economische en Sociale Geografie, 109(4), 470-484.

Amelina, A. (2017). After the reflexive turn in migration studies: Towards the doing migration approach (Working Paper Series 'Gender, Diversity and Migra- tion,' No. 13). Frankfurt: Goethe University Frankfurt. Aybek, C. (2009). München: Integrationspolitik nach dem Neuen Steuerungsmodell: Migration und Integration als Herausforderung von Kommunen [Munich: Integration policy according to the new governance model: Migration and integration as a challenge for local authorities]. In F. Gesemann \& R. Roth (Eds.), Lokale Integrationspolitik in der Einwanderungsgesellschaft [Local integration policy in the immigration society] (pp. 335-350). Wiesbaden: VS Verlag für Sozialwissenschaften.

Barbehön, M., \& Münch, S. (2016). The distinctiveness of cities and distinctions in cities: Boundaries of belonging in comparative perspective. Urban Research \& Practice, 9(1), 37-55.

Barlett, L., \& Vavrus, F. (2017). Comparative case studies: An innovative approach. Nordic Journal of Comparative and International Education, 1(1), 5-17. http://doi.org/10.7577/njcie.1929

Berding, N. (2019). Die Blasiertheit der Städter*innen: Vom routinierten Umgang mit alltäglicher Komplexität [The blasé attitude of city dwellers: The routine handling of everyday complexity]. Geographica Helvetica, 74, 183-192. https://doi.org/10.5194/gh-74183-2019

Berg, M. L., \& Sigona, N. (2013). Ethnography, diversity and urban space, identities. Global Studies in Culture and Power, 20, 347-360. https://doi.org/10.1080/ 1070289X.2013.822382

Biehl, K. (2015). Spatializing diversities, diversifying spaces: Housing experiences and home space perceptions in a migrant hub of Istanbul. Ethnic and Racial Studies, 38(4), 596-607. https://doi.org/ 10.1080/01419870.2015.980293

Bojadžijev, M., \& Römhild, R. (2014). Was kommt nach dem 'transnational turn'? Perspektiven für eine kritische Migrationsforschung [What follows after the transnational turn? Perspectives for a critical migration research]. In Labor Migration (Eds.), Vom Rand ins Zentrum [From the margins to the center] (pp. 10-24). Berlin: Panama.

City of Leipzig. (2013). Gesamtkonzept zur Integration der Migrantinnen und Migranten in Leipzig [Overall concept for the integration of migrants in Leipzig]. Leipzig: City of Leipzig.

City of Leipzig. (2018a). INSEK: Entwurf Integriertes Stadtentwicklungskonzept "Leipzig 2030" [Draft integrated urban development concept]. Leipzig: City of Leipzig.

City of Leipzig. (2018b). Integriertes Handlungskonzept: soziale Stadt Paunsdorf [Integrated action plan: Paunsdorf-a social city]. Leipzig: City of Leipzig.

Dahinden, J. (2016). Migration im Fokus? Plädoyer für eine reflexive Migrationsforschung [Migration in focus? A plea for reflective migration research]. In C. Schellenbacher, J. Dahlvik, H. Fassmann, C. Reinprecht, \& V. Runipress (Eds.), Migration und Integration: wissenschaftliche Perspektiven aus Österreich 
[Migration and integration: Scientific perspectives from Austria] (pp. 11-30). Göttingen: v \& r unipress.

El-Mafaalani, A. (Eds.). (2018). Das Integrationsparadox: Warum gelungene Integration zu mehr Konflikten führt [The integration paradox: Why successful integration leads to more conflicts]. Cologne: Kiepenheuer \& Witsch.

Empirica. (2011). Urban development measure Nordhaide: Social science study for the residential quarter Nordhaide, commissioned by LH München. Berlin: Empirica.

Espahangizi, K. (2016, June 12). Das \#Postmigrantische ist kein Kind der Akademie [The \#Postmigrant is not a child of the Academy]. Geschichte der Gegenwart. Retrieved from https://geschichtedergegenwart.ch/ das-postmigrantische-kein-kind-der-akademie

Foroutan, N. (2015). Die Einheit der Verschiedenen: Integration in der postmigrantischen Gesellschaft [The unity of the different: Integration in the postmigrant society]. Bonn: Bundeszentrale für politische Bildung.

Foroutan, N. (2016). Postmigrantische Gesellschaften [Postmigrant societies]. In H. Brinkmann \& M. Sauer (Eds.), Einwanderungsgesellschaft Deutschland [Immigration society Germany] (pp. 227-254). Wiesbaden: Springer.

Foroutan, N. (2018). Migration als Chiffre [Migration as a cipher]. In M. Perinelli (Ed.), Die Macht der Migration [The power of migration] (pp. 19-29). Münster: Rosa-Luxemburg Stiftung.

Glaser, B. G., \& Strauss, A. L. (1979). Die Entdeckung gegenstandsbezogener Theorie [The discovery of subject-related theory]. In C. Hopf \& E. Weingarten (Eds.), Qualitative Sozialforschung [Qualitative social research] (pp. 91-111). Stuttgart: Klett-Cotta.

Glick-Schiller, N., \& Çağlar, A. (2009). Towards a comparative theory of locality in migration studies: Migrant incorporation and city scale. Journal of Ethnic and Migration Studies, 35(2), 177-202.

Glick-Schiller, N., Çağlar, A., \& Guldbrandsen, T. C. (2006). Beyond the ethnic lens: Locality, globality, and bornagain incorporation. American Ethnologist, 33(4), 612-633.

Ha, K. N., \& Schmiz, M. (2006). Der nationalpädagogische Impetus deutscher Integrations(dis)kurse im Spiegel postkolonialer Kritik [The national pedagogical impetus of German integration (dis)courses in the mirror of postcolonial criticism]. In P. Mecheril \& M. Witsch (Eds.), Cultural Studies und Pädagogik [Cultural studies and pedagogics] (pp. 226-266). Bielefeld: Transcript.

Hall, S. (2015). Super-diverse street: A 'trans-ethnography' across migrant localities. Ethnic and Racial Studies, 38(1), 22-37.

Helbig, M., \& Jähnen, S. (2018). Wie brüchig ist die soziale Architektur unserer Städte? [How fragile is the social architecture of our cities?] (Discussion Paper $\mathrm{P}$ 2018-001). Berlin: Wissenschaftszentrum Berlin für
Sozialforschung.

Hess, S., \& Moser, J. (2015). Jenseits der Integration: Kulturwissenschaftliche Betrachtungen einer Debatte [Beyond integration: Cultural studies considerations of a debate]. In S. Hess, J. Binder, \& J. Moser (Eds.), No integration?! Kulturwissenschaftliche Beiträge zur Integrationsdebatte in Europa [No integration?! Cultural studies contributions to the debate on integration in Europe] (pp. 11-25). Bielefeld: Transcript.

Hill, M., \& Yildiz, E. (2018). Einleitung [Introduction]. In M. Hill \& E. Yildiz (Eds.), Postmigrantische Visionen. Erfahrungen-Ideen-Reflexionen [Postmigrant visions. Experience-ideas-reflections] (pp. 7-19). Bielefeld: Transcript.

Hinger, S., \& Schäfer, B. (2019). Making a difference: The accommodation of refugees in Leipzig and Osnabrück. Erdkunde, 73(1), 63-76.

Huss, E. (2010). Migranten-Milieus[Migrant milieus]. Münchner Statistik, 1(2010), 1-14.

Kirndörfer, E. (2019). Feuerlöschen im Brennpunkt. Vom Umgang mit Differenz und den Mirkoordnungen des Alltags in einem Jugendclub in Leipzig-Paunsdorf [Dealing with difference and the micro-orders of everyday life in a youth club in Leipzig-Paunsdorf] (Project Report). Unpublished manuscript.

Langhoff, S. (2012, January 23). Wozu postmigrantisches Theater? [Postmigrant theatre what for?]. Faz. Retrieved from https://www.faz.net/aktuell/ feuilleton/buehne-und-konzert/gespraech-mitshermin-langhoff-wozu-postmigrantisches-theater11605050.html

LH München. (2012). Projektinformation Nordhaide [Project Information Nordhaide]. LH München. Retrieved from https://www.muenchen.de/rathaus/ Stadtverwaltung/Referat-fuer-Stadtplanung-undBauordnung/Projekte/Nordhaide.html

Münch, S. (2013). Rahmenbedingungen von Zuwanderung und interkulturellem Zusammenleben in den ostdeutschen Bundesländern: eine Bestandsaufnahme Framework conditions of immigration and intercultural coexistence in the East German states: A stocktaking]. Raumforschung und Raumordnung, 71, 261-271.

Pilz, M. (2019). Stadtteilarbeit: Bewohnerzentrum Nordhaide: Mitarbeiterinnen gestalten Gesellschaft [District work: Nordhaide residents' centre: employees shape society]. Bunnyhill Express, Diakonie Hasenbergl, 22, 40-41.

Pott, A. (2018). Migrationsregime und ihre Räume [Migration regimes and their spaces]. In A. Pott, C. Rass, \& F. Wolff (Eds.), What is a migration regime? (pp. 107-135). Wiesbaden: VS Verlag für Sozialwissenschaften.

Przyborski, A., \& Wohlrab-Sahr, M. (2014). Qualitative Sozialforschung: Ein Arbeitsbuch [Qualitative social research: A workbook]. Reihe: De Gruyter.

Pütz, R., \& Rodatz, M. (2013). Kommunale Integrationsund Vielfaltskonzepte im Neoliberalismus: Zur strate- 
gischen Steuerung von Integration in deutschen Großstädten [City strategies on diversity and integration under neoliberal conditions. Strategic management of integration in major German cities]. Geographische Zeitschrift, 101(3/4), 166-183.

Robinson, J. (2006). Ordinary cities: Between modernity and development. London: Routledge.

Römhild, R. (2017). Beyond the bounds of the ethnic: For postmigrant cultural and social research. Journal of Aesthetics \& Culture, 9(2), 69-57.

Saunders, D. (2010). Arrival city: How the largest migration in history is reshaping our world. London: Random House.

Schmiz, A., \& Räuchle, C. (2019). Introduction to the special issue: Comparing local refugee regimes. Erdkunde, 73(1), 3-7.

Schnur, O. (2008). Quartiersforschung im Überblick: Konzepte, Definitionen und aktuelle Perspektiven [An overview of neighbourhood research: Concepts, definitions and current perspectives]. In O. Schnur (Ed.), Quartiersforschung: Zwischen Theorie und Praxis [Neighbourhood research: Between theory and practice] (pp. 19-54). Wiesbaden: VS Verlag für Sozialwissenschaften.

Vertovec, S. (2007). Super-diversity and its implications. Ethnic and Racial Studies, 30(6), 1024-1054.

Wessendorf, S. (2013). Commonplace diversity and the 'ethos of mixing': Perceptions of difference in a London neighbourhood, identities. Global Studies in Culture and Power, 20(4), 407-422.

Wiest, K., \& Kirndörfer, E. (2019). Paradoxe Aushandlungen von Migration im Diskurs um die Leipziger Eisenbahnstraße [Paradoxical negotiations of migration in discourses around the Eisenbahnstraße in the city of Leipzig]. Raumforschung und Raumordnung, 74, 273-283. https://doi.org/10.2478/rara-2019-0030

Wise, A., \& Noble, G. (2016). Convivialities an orientation. Journal of Intercultural Studies, 37(5), 423-431.

\section{About the Author}

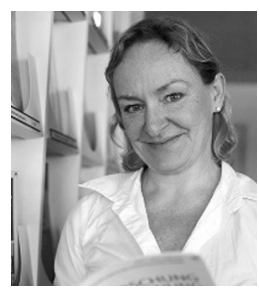

Karin Wiest is Senior Researcher at the Leibniz Institute for Regional Geography (IfL), Germany. Her research interests are focused on comparative urban studies, migration studies, socio-spatial inequalities, socio-spatial processes in urban and rural contexts in Germany and the EU countries. Currently she is leading the project 'Dealing with Diversity on the Societal Margins of the Postmigrant City' funded by the German Research Foundation. 